\title{
METHODS FOR DETERMINING THE BOTANICAL ORIGIN OF HONEY
}

\author{
Leonora Adamchuk, Vladyslav Sukhenko, Oleksandra Akulonok, Tetiana Bilotserkivets, \\ Volodymyr Vyshniak, Dina Lisohurska, Olha Lisohurska, Natalia Slobodyanyuk, Olga Shanina, \\ Ivan Galyasnyj
}

\begin{abstract}
The demand for monofloral, original, and special (functional) kinds of honey, or those with geographical indication, is forecast. At the same time, there is a need to improve the methods for determining the botanical and geographical origin of honey. The purpose of the research was to select and apply a variety of techniques for identifying the botanical origin of honey for its correspondence to acacia species. Samples of honey from the Kyiv, Odesa, and Dnipro regions extracted in the spring and summer period were used in the research. Organoleptic, physicochemical, NMR spectrometry, and advanced melissopalynology methods were applied. The tests were carried out at the laboratories of the Department of Certification and Standardization of Agricultural Products, NULES, Ukraine; the Ukrainian Laboratory of Quality and Safety of Agricultural Products; and the Bruker BioSpin GmbH company (Germany). According to the research results, the requirements for acacia honey were met by the organoleptic method for samples B1 and B2; by the physicochemical method for A0 and A2; by NMR spectroscopy for not a single sample, all being assessed as polyfloral; and by pollen analysis for B1 and B2. The conducted studies confirm the need for a comprehensive approach to the identification of the botanical origin of honey for its conformity to acacia species. There is a need to review the physicochemical indicators for the compliance of honey with the acacia species obtained in Ukraine. After all, even the modern NMR spectrometry technique indicated that the specially fabricated sample that did not contain acacia pollen grains was acacia honey. Identification of the botanical origin of monofloral honey, in particular acacia, should be carried out in the following sequence: pollen analysis (by dominant pollen grains), safety (presence of antibiotics, pesticides), physicochemical parameters according to international requirements, organoleptic parameters.
\end{abstract}

Keywords: acacia honey; evaluation; method; NMR spectrometry

\section{INTRODUCTION}

According to Global Industry Analysts Inc. USA (2016), the global honey market is projected to reach 2.4 million tonnes by 2022. Carreck (2018) believes that much of this growth is due to the demand for monofloral and special (functional) kinds of honey, or those that have a specific geographical region of origin. That is the relevance of our research, along with the improvement of the methods for determining the botanical and geographical origin of honey, methods of analysis and discrimination of individual varieties of product, its safety, and quality.

At the moment, the current regulatory and technical documentation in different countries of the world governing the safety and quality of honey is not harmonized. There are differences between European legislation and Codex Alimentarius standards. Also, different countries maintain up-to-date quality criteria that do not comply with the Codex or EU directives on honey.
The necessity to establish national requirements for each country (harmonized with international ones) is mainly due to the lack of provisions regarding the physicochemical characteristics of monofloral honey and the declaration of its geographical origin (Thrasyvoulou et al., 2018).

There are currently two documents in Ukraine governing the safety and quality of honey, DSTU 4497:2005 (2007) and Nakaz MinAPK No. 330 (2019). Therefore, the search for methods that allow the main botanical varieties and geographical species of Ukrainian honey to be studied is a relevant area for analysis and subsequent research.

It has been established (Ulloa et al., 2013; Lenhardt et al., 2015; Machado De-Melo et al., 2018; Maione, Barbosa and Barbosa, 2019) that the organoleptic and physicochemical characteristics of honey vary depending on botanical and geographical origin, as well as climatic conditions, processing and storage. And other bee products as well (Ivanišová et al., 2015). 
It is relevant to use honey as a biomarker to collect environmental information, identify sources of environmental contamination and assess soil, water and air pollution (Machado De-Melo et al., 2018). One of the first and most common methods of determining the botanical origin of honey is melissopalynology, that is, a microscopic analysis of the pollen contained in honey shows the nectar content of certain plants.

Maione, Barbosa and Barbosa (2019) consider that it is still used as one of the most accurate methods for qualitative or quantitative analysis of the content of pollen grains in honey. Along with this, there are several modern techniques. The botanical origin of honey is identified by PARAFAC (parallel factor) analysis of excitation emission matrix fluorescence spectra (Lenhardt et al., 2015). Emissions of phenolic compounds and Maillard reaction products reveal the greatest difference among honey varieties of different botanical origin. Falsified honey samples with $100 \%$ sensitivity to variety compliance can be detected using the partial least squares discriminant analysis (PLSDA) classification model based on PARAFAC models. Among the honey samples tested, PLSDA identifies linden with a difference of $0.5 \%$, acacia with $10 \%$, and sunflower and polyfloral meadow honey with differences of about $20 \%$ compared to the results of pollen analysis. The disadvantage of the method is the large discrepancy between the results obtained even within the same honey variety, which indicates the need for its improvement.

Soares et al. (2015) proposed the use of DNA-based methods for the identification of botanical honey species. For this, five DNA extraction methods were used (NucleoSpin Plant Kit (methods A and B) and DNeasy Plant Mini Kit, as well as internal CTAB and Wizardbased methods). The results demonstrated that the Wizard method had the best performance in terms of DNA quality. The disadvantages of DNA-based methods are their cost and unsuitability to industrial conditions of use.

Today, the use of analytical methods is becoming widespread. Mainly, this concerns nuclear magnetic resonance (NMR) spectroscopy for the authentication of honey (botanical and geographical origin).

Siddiqui et al. (2017) consider NMR spectroscopy to be sufficiently powerful and accurate, and therefore suitable for creating prints for honey of different origin for their further comparison. In Romania, studies on stable isotopes, selected as representative discrimination parameters of different botanical or geographical origin of honey, have been conducted using isotope ratio mass spectrometry (IRMS) and site-specific natural isotope fractionation measured by nuclear magnetic resonance (SNIF-NMR) methods. The authors (Dinca et al., 2015) confirmed the high efficiency of the method but emphasized the need to create an informative base for prints of honey of different botanical origin.

Gok et al. (2015) established the predictive ability of Fourier transform infrared (FTIR) spectroscopy and chemometrics to determine the botanical composition of honey. Cozzolino, Corbella and Smyth (2011) proposed spectroscopic methods in the infrared (IR) wavelength range of the electromagnetic spectrum to evaluate and control the composition of honey. The use of IR spectroscopic technologies has its place in the determination of the botanical origin of honey by comparing the spectra of the mid-infrared (MIR) spectrum.

Etzold and Lichtenberg-Kraag (2008) used the most common types of honey for calibration, and classification models were obtained by calibration of principal components analysis (PCA) and properly graded FTIR concerning the physicochemical and sensory properties of the selected samples.

To improve honey discrimination, Corvucci et al. (2015) proposed the use of FT-micromanaging spectrography and multivariate analysis. At the same time, successful results using the PCA model have also been achieved by other authors. This method is currently being refined and enhanced.

Modern sensory methods include the use of an electronic nose (e-nose) in multivariate analysis and selection of sensors to detect the botanical origin and determine honey quality. Huang et al. (2015) first implemented three sensor selection algorithms, namely, uninformation variable elimination (UVE), successive projections algorithm (SPA) and competitive adaptive reweighted sampling (CARS), which were applied to analyse the enose fingerprints of honey. Three different sampling modes were tested for the classification of monofloral honey: static headspace sampling (SHS), solid-phase microextraction (SPME) and inside needle dynamic extraction (INDEX). The last two showed better ability to remove volatile components. In subsequent experiments, preference was given to the SPME sampling mode, which proved to be more accurate.

Ampuero, Bogdanov and Bosset (2004) found a positive correlation between e-nose and pollen analysis of honey. Discriminant function analysis (DFA) was also conducted using an e-nose based on a mass spectrometer when the DFA diagram indicated a significant separation of honey odours from other odour sources (Hong et al., 2011). Thus, the e-nose method can be used to identify honey but needs further refinement.

Ulloa et al. (2013) investigated a method for determining the botanical origin of honey using sensory synthesis of impedance electronic language (e-language) and optical spectroscopy (UV-Vis-NIR), namely, PCA and cluster analysis (CA).

In 2016, the mathematical method for identifying honey was first described. Gan et al. (2016) considered the use of PLSDA, a support vector model (SVM), and an interval partial least squares model (iPLS). The results showed that the spectra and sensors classified the botanical origin of honey quickly and accurately, and the overall accuracy for the calibration and forecasting set was $100 \%$ for e-nose and electronic tongue (ET) analysis using the SVM model and near-infrared (NIR) and MIR analysis using the iPLS model. At the same time, overall accuracy for calibration and forecasting sets was above $96 \%$ in PLSDA NIR, MIR and ET models. The results showed that ET is more suitable for detecting botanical falsification of honey. However, there is a need to create calibration and forecasting sets for each sample of honey produced in the world. This makes it impossible to use this method in practice.

Son et al. (2019) investigated whether the zymography of nectar chitinases is a potential marker for determining or validating the botanical origin of honey. However, 
zymography is the first examination of the activity of nectar enzyme in honey. This method is also being refined.

Chekryga, Niczievskaya and Borodaj (2019) have proposed a method for determining the botanical origin of honey, which is to use a natural drop of a honey sample without pre-treatment. According to the authors, the advantage of the proposed method over others is that when using it there is no deformation of pollen grains, which are in a natural state, including their spatial location. However, the proposed method casts doubt on the quantitative evaluation of pollen grains and the reliability of the analysis results due to the uneven arrangement of grains of different weights in the thickness of honey.

Sensory data obtained from ET and e-nose histograms of honey colour show a high discriminatory ability to determine the origin of honey. Therefore, many authors (Machado De-Melo et al., 2018; Pascual-Maté et al., 2018) believe that PCA, discriminant analysis (DA) and $\mathrm{CA}$ are the best methods for performing the experimental and predictive method for determining the origin of honey. PCA and DA continue to be favoured due to their ease of application and interpretation, while machine learning algorithms are more complex for modelling and the use of classifiers. Nevertheless, the use of both machine learning algorithms and PCA-DA models have achieved excellent results for discrimination of the origin of honey. Finally, a common trend is the use of hybrid methods that combine multivariate analysis of data and methods (Peng Kek et al., 2017; Machado De-Melo et al., 2018; Pascual-Maté et al., 2018).

Ballabio et al. (2018) performed a comparative evaluation of methods for determining the botanical origin of honey. Thus, IR, NIR, Raman spectroscopy, PTR-ToFMS and e-nose methods were applied to samples of common botanical varieties of honey. The best results were obtained with the synthesis of the NIR method and Raman spectroscopy, as well as PTR-ToF-MS. The accuracy of the final model was $99 \%$ on the test specimens and $100 \%$ on the calibration.

In Ukraine, due to a lack of the necessary equipment, only various pollen analysis techniques are used to identify the origin of honey. Therefore, the purpose of our work was to select and apply a variety of techniques to identify the botanical origin of honey for its correspondence to acacia variety.

\section{Scientific hypothesis}

According to many scientists, modern methods of researching honey can replace the classical methods of determining its botanical origin, such as pollen analysis and organoleptic evaluation. In studies, we expect to refute the view that NMR spectroscopy allows determination of the falsification of acacia honey without the use of melissopalynological research, provided that the geographical origin of the honey is not known.

As a result, one of the samples was falsified in a sophisticated manner and NMR spectroscopy did not reveal this. Also, two specimens were identified as acacia monofloral honey by pollen and organoleptic analyses. Instead, NMR spectroscopy showed that one of these samples did not meet the requirements for acacia honey by physicochemical parameters.

\section{MATERIAL AND METHODOLOGY}

\section{Biological material}

The research used honey samples obtained from the Kyiv, Odesa and Dnipro regions obtained in the spring and summer that could be realized on the market as acacia. Honey from bees was collected in March - May 2018. The samples were stored in glass containers at +15 to $+20{ }^{\circ} \mathrm{C}$ away from sunlight until the start of the research in August 2018.

\section{Honey samples}

Sample A0 was obtained from nectar mixed with sugar syrup by bees (stored in the fall), which they processed into honey, put in cells and sealed; the sample was obtained from bees in the form of honey in March 2018 (Kyiv region). A1 - honey centrifuged from bee honeycombs in May 2018 (Kyiv region); A2 - in June 2018 (Kyiv region); B1 - in May 2018 (Odesa region); B2 - May 2018 (Dnipro region). Acacia bloom in Ukraine is due in May.

\section{Organoleptic analysis}

The analysis was conducted at the laboratories of the Department of Certification and Standardization of Agricultural Products, National University of Life and Environmental Sciences (NULES) of Ukraine, with the use of the methodology and requirements specified according to DSTU 4497:2005 (2007).

\section{Physicochemical analysis}

The analysis was conducted at the Ukrainian Laboratory of Quality and Safety of Agricultural Products.

\section{Chemicals}

All chemicals were of analytical grade and were purchased from LLC "NVP"ALFARUS" (UA).

\section{Mass fraction of water}

The mass fraction of water was determined on an LR-01 laboratory refractometer (Maselli Misure s.p.a., Italy) using a standardized technique according to DSTU 4497:2005 (2007).

\section{Hydroxymethylfurfural, diastasis and proline}

Hydroxymethylfurfural, diastasis and proline were investigated with a KFC-3 photocalorimeter (Russia) using standardized methods according to DSTU 4497:2005 (2007). All the techniques have been pre-elaborated and described in detail for acacia honey of different geographical origin (Adamchuk, Suchenko and Akulonok, 2019).

\section{NMR spectrometry}

The analysis was carried out at the laboratories of Bruker BioSpin GmbH (Bruker, 2020) (Germany) using Avance Neo and Benchtop NMR Fourier 80 devices (Germany) and a technique which allows the acquisition of a fingerprint to confirm the authenticity of the product or reveal adulteration by addition of sweetener (Schievano et al., 2020). All NMR samples were prepared by dissolving $\sim 240 \mathrm{mg}$ honey in phosphate buffer solution $\left(\mathrm{KH}_{2} \mathrm{PO}_{4}\right.$ in 
$\left.\mathrm{D}_{2} \mathrm{O}\right)$, adjusting the honey $(\mathrm{mg}) /$ buffer $(\mathrm{mL})$ ratio to exactly $240 \mathrm{mg} \cdot \mathrm{mL}^{-1}$. The $\mathrm{pD}$ was carefully adjusted from 133 to 4.40 .

\section{Botanical origin}

Botanical origin was determined according to the adapted harmonized methods of melissopalynology (Von Der Ohe et al., 2004) using a Sigeta Biogenic Led Trino Infinity microscope (China) with $400 \times$ and $2000 \times$ magnification based in the laboratories of the Department of Certification and Standardization of Agricultural Products, NULES of Ukraine with the use of DSTU 4497:2005 (2007). Identification of plants was carried out according to the methodology and experience of the team of the international network AgroBioNet (Brindza et al., 2018).

\section{Statistical analysis}

Basic statistical analysis was carried out using SAS programming packages (SAS System V9.2). Correlation coefficients were calculated by CORR analysis (SAS, 2009).

\section{RESULTS AND DISCUSSION}

In organoleptic research on honey for compliance with acacia variety requirements, evaluations were made by colour, taste, aroma, consistency, crystallization and the presence of signs of fermentation and mechanical impurities. The results of the organoleptic research are shown in Table 1.

According to the results of the organoleptic evaluation, only samples B1 and B2 met the requirements for acacia honey. Sample A0 had the lowest compliance (14\%).
Among the physicochemical indicators were those that indicate the naturalness and enzymatic activity of honey diastase number, and proline and hydroxymethylfurfural content. Also, they have values that are different from other honey varieties. The results are shown in Table 2.

According to the conducted studies, in terms of the mass fraction of water, hydroxymethylfurfural and diastasis number, all tested honey samples met the requirements. The highest proline content was found in the falsified sample A0 - $483.7 \pm 0.36 \mathrm{mg} \cdot \mathrm{kg}^{-1}$, which is $76 \%$ and $54 \%$ higher than the other samples from Kyiv region, which did not correlate with acacia varieties by organoleptic indicators; and $71 \%$ higher than the honey samples that corresponded to acacia species in organoleptic indicators (B1 and B2).

In general, according to the physicochemical parameters investigated, samples A0 and A2 corresponded to the requirements of DSTU 4497:2005 (2007) for acacia honey. At the same time, according to the requirements of another current regulatory document, which is used today for the circulation of the product in the country and its export, all the research samples met the established criteria.

Thus, according to the results of honey studies, which were carried out by standardized methods, the data obtained differed by organoleptic and physicochemical parameters in accordance with the acacia variety. By the latter, two samples, one of which was a pre-prepared falsification (A0), fully met the requirements for acacia honey compliance. This speaks about the need to review complex methods of evaluating honey to identify it as an acacia variety.

Table 1 Organoleptic honey research.

\begin{tabular}{|c|c|c|c|c|c|c|c|}
\hline \multirow{2}{*}{ No. } & \multicolumn{2}{|r|}{ Indicator } & \multicolumn{5}{|c|}{ Honey sample } \\
\hline & Name & Characteristic & A0 & A1 & A2 & B1 & B2 \\
\hline 1. & Color & Colorless, light yellow, transparent & - & - & - & + & + \\
\hline 2. & Crystallization & Absent & - & + & + & + & + \\
\hline 3. & Signs of fermentation & Prohibited & - & - & - & + & + \\
\hline 4. & Taste & Sweet, delicate, without any foreign flavors & - & - & - & + & + \\
\hline 5. & Aroma & Very weak, no odours & - & - & - & + & + \\
\hline 6. & $\begin{array}{l}\text { Consistency } \\
\text { (liquid) }\end{array}$ & $\begin{array}{c}\text { A small amount of honey is left on the spatula, which } \\
\text { quickly drains into small drops }\end{array}$ & - & + & - & + & + \\
\hline 7. & Mechanical impurities & Prohibited & + & + & + & + & + \\
\hline \multicolumn{3}{|c|}{ Compliance with acacia honey variety, \% } & 14 & 43 & 29 & 100 & 100 \\
\hline
\end{tabular}

Note: $(+)$ - meets the requirements for acacia honey; $(-)$ - does not meet the requirements for acacia honey.

Table 2 Physicochemical honey research $(n=2)$.

\begin{tabular}{|c|c|c|c|c|c|}
\hline Sample & $\begin{array}{c}\text { Mass fraction } \\
\text { of water, no } \\
\text { more than, \% }\end{array}$ & $\begin{array}{l}\text { HMF, no more } \\
\text { than, mg.kg-1 }\end{array}$ & $\begin{array}{c}\text { Diastasis, no } \\
\text { less than, } \\
\text { Goethe units } \\
\end{array}$ & $\begin{array}{c}\text { Proline, no less } \\
\text { than, } \mathrm{mg} \cdot \mathrm{kg}^{-1}\end{array}$ & \multirow{3}{*}{$\begin{array}{l}\text { Compliance with the } \\
\text { DSTU requirements } \\
\text { for acacia honey, \% }\end{array}$} \\
\hline Standard $^{D}$ & $18.5^{\mathrm{HG}} \quad 21^{\mathrm{FG}}$ & 25 & $\begin{array}{ll}15 & 5\end{array}$ & 200 & \\
\hline Standard $^{N}$ & 20 & 40 & 3 & 100 & \\
\hline A0 & 16.6 & $7.9 \pm 0.19$ & $20.3 \pm 0.11$ & $483.7 \pm 0.36$ & 100 \\
\hline A1 & 15.0 & $7.7 \pm 0.00$ & $19.1 \pm 0.16$ & $118.2 \pm 0.73$ & 75 \\
\hline A2 & 16.2 & $7.4 \pm 0.19$ & $31.0 \pm 0.05$ & $220.5 \pm 0.36$ & 100 \\
\hline B1 & 16.6 & $2.2 \pm 0.10$ & $10.0 \pm 0.05$ & $141.2 \pm 0.73$ & 75 \\
\hline $\mathrm{B} 2$ & 16.8 & $1.6 \pm 0.10$ & $9.6 \pm 0.10$ & $139.2 \pm 0.10$ & 75 \\
\hline
\end{tabular}

Note: D -standard defined in DSTU 4497:2005; N -standard defined in Nakaz MinAPK No. 330 dated 19.06.2019;

$\mathrm{HG}$ - highest grade; FG - first grade; HMF - hydroxymethylfurfural. 


\begin{tabular}{clccccc}
\hline \multicolumn{7}{c}{ Table 3 NMR spectroscopy of sugars in honey, $\mathrm{g} .100 \mathrm{~g}^{-1}$. } \\
\hline No. & \multicolumn{1}{c}{ Indicator } & $\mathbf{A 0}$ & $\mathbf{A 1}$ & $\mathbf{A 2}$ & $\mathbf{B 1}$ & B2 \\
\hline 1. & Glucose + fructose & 74.1 & 74.4 & 73.8 & 75.6 & 78.2 \\
2. & Fructose/glucose & 1.34 & 1.54 & 1.38 & 1.68 & 1.30 \\
3. & Fructose & 42.4 & 45.1 & 42.7 & 47.4 & 44.2 \\
4. & Glucose & 31.7 & 29.3 & 31.1 & 28.2 & 33.9 \\
5. & Saccharose & 0.7 & 2.5 & 1.1 & 3.5 & 0.6 \\
6. & Turanose & 1.7 & 2.7 & 2.4 & 2.9 & 1.9 \\
7. & Maltose & 2.4 & 2.7 & 2.6 & 3.3 & 2.2 \\
8. & Raffinose & 0.2 & 0.3 & 0.2 & 0.2 & 0.1 \\
\hline
\end{tabular}

Table 4 Honey-Profiling ${ }^{\mathrm{TM}}$ profile for sugars according to NMR spectroscopy.

\begin{tabular}{|c|c|c|c|c|c|}
\hline Indicator & A0 & A1 & A2 & B1 & B2 \\
\hline Glucose + fructose & ${ }^{62.8} \curvearrowleft 1$ & ${ }^{62.8} \curvearrowleft 1{ }^{86.2}$ & ${ }^{62.8} \longmapsto 1{ }^{86.2}$ & ${ }^{62.8} \frown 1{ }^{86.2}$ & ${ }^{62.8} \curvearrowleft 1{ }^{86.2}$ \\
\hline Fructose/glucose & ${ }_{0.88} \perp^{1.58}$ & $0.88 \curvearrowleft \boldsymbol{L}_{1.58}$ & ${ }_{0.88} \curvearrowleft \perp^{1.58}$ & ${ }^{0.88} \curvearrowleft \bigcup^{1.58}$ & ${ }_{0.88} \curvearrowleft \perp^{1.58}$ \\
\hline Fructose & ${ }^{32.9} \curvearrowleft \perp^{45.4}$ & $\left.{ }^{32.9} \curvearrowleft\right|_{45.4}$ & ${ }^{32.9} \curvearrowleft \perp_{1}{ }^{45.4}$ & $32.9 \curvearrowleft \underbrace{}_{45.4}$ & ${ }_{32.9} \perp_{45.4}$ \\
\hline Glucose & ${ }^{25.6} \not 1{ }^{43.9}$ & ${ }_{25.6} \perp{ }^{43.9}$ & ${ }^{25.6} \curvearrowleft{ }^{43.9}$ & ${ }^{25.6} \perp{ }^{43.9}$ & ${ }^{25.6} \curvearrowleft 1{ }^{43.9}$ \\
\hline Saccharose & $<0.51 \longrightarrow 2.9$ & $<0.5 \triangleright L_{4} 2.9$ & $<0.5 \mathrm{P}{ }^{2.9}$ & $<0.5 \longmapsto 2.9$ & $<0.51 \quad 2.9$ \\
\hline Turanose & $0.4 \longmapsto 1 r^{3.0}$ & $0.4 \longmapsto \perp_{3} 3.0$ & $0.4 \perp_{3}{ }^{3.0}$ & ${ }_{0.4}$ 工 $_{3.0}$ & $1,3.0$ \\
\hline Maltose & $<0.5 \bigcirc \perp^{3.6}$ & $<0.5 \bigcirc \perp^{3.6}$ & $<0.5 \bigcirc 1{ }^{3.6}$ & $<0.5 \curvearrowleft \perp^{3.6}$ & $<0.5 \bigcirc 1{ }^{3.6}$ \\
\hline Melezitose & $<1.0 \bigsqcup$ & $<1.0 \bigsqcup$ & $<1.0 \bigsqcup \quad{ }^{1.1}$ & $<1.0{ }{ }^{1.1}$ & $<1.01$ \\
\hline Maltotriose & $<1.0 \mathrm{~g} \cdot 10 \mathrm{~g}^{1} \mathrm{I}^{\text {in reference dataset }}$ & $<1.0 \mathrm{~g}_{100 \mathrm{~g}^{-1} \text { in reference dataset }}$ & $<1.0 \mathrm{~g}, 100 \mathrm{~g}^{-1}$ in reference dataset & $<1.0 g_{100 g^{1}}$ in refference dataset & $<1.0$ g. $100 g^{-1}$ in reference dataset \\
\hline Gentiobiose & $<0.31$ & $<0.31$ & $\longrightarrow^{0.4}$ & $<0.3 \mathrm{~L}$ & $<0.3 L$ \\
\hline Raffinose & $<0.1 \triangleright$ & $<0.1 \longmapsto 1{ }^{0.4}$ & $<0.1 \longmapsto{ }^{0.4}$ & $<0.1 \longmapsto{ }^{0.4}$ & $<0.1 \perp$ \\
\hline Mannose & $<0.05 \perp{ }^{0.23}$ & $<^{20.5} \longrightarrow{ }^{0.23} \mathrm{C}$ & $0.23 \mathrm{~d}$ & $\longrightarrow^{0.23} \mathrm{CO}$ & $<0.05 \mathrm{~L}$ \\
\hline
\end{tabular}

\subsection{8}

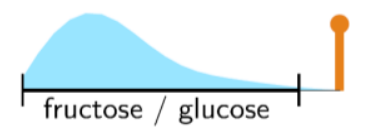

1.58

32.9

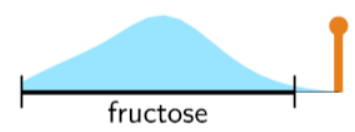

45.4

Figure 1 Discrepancy between the honey profile of sample B1 and the reference NMR database.

The next step was the evaluation of honey samples using a modern NMR spectroscopy technique that is widely used in internationally accredited laboratories. Its core consists of the complex analysis of physicochemical parameters, on the basis of which the profile of the honey is programmatically constructed and its botanical origin determined. NMR spectroscopy of honey made it possible to analyse 12 indicators for sugar, including the ratio of fructose to glucose (Table 3 ).

According to our data, the ratio of fructose to glucose (FG) ranged from 1.30 to 1.68 . According to studies of the acacia honey profile by other scientists (Marghitas et al., 2010), it is known that the FG index ranges from 1.43 to 1.57 (the content of acacia pollen grains in honey was in the range from $20.0 \%$ to $30.2 \%$ ). According to other data (Oddo et al., 2004), the highest average FG value for acacia honey from Europe is 1.61 (715 samples tested). At the same time, honey from Ukraine is accepted for export as acacia if $\mathrm{FG}$ is more than 1.5.
According to Marghitas et al. (2010) and Schievano et al. (2020), sucrose and maltose content may also indicate botanical origin. Thus, for acacia honey, Marghitas et al. (2010) found that the sucrose content in acacia varieties ranged from 0.59 to $2.50 \mathrm{~g} .100 \mathrm{~g}^{-1}$, and the maltose content from 2.31 to 3.07 g. $100 \mathrm{~g}^{-1}$. In addition, Nakaz MinAPK No. 330 allows a sucrose content of not more than 10 g. $100 \mathrm{~g}^{-1}$, and maltose is not specified. Thus, for sucrose, the honey we studied met the requirements for acacia variety compliance. The presence of sugars other than those listed in Table 3 was investigated, but their quantitative values were beyond the limit of determination. Among these were melezitose (limit of determination 1 g. $\left.100 \mathrm{~g}^{-1}\right)$, maltotriose (1 g. $\left.100 \mathrm{~g}^{-1}\right)$, gentiobiose $\left(0.3 \mathrm{~g} .100 \mathrm{~g}^{-1}\right)$ and mannose $\left(0.05 \mathrm{~g}^{-100 \mathrm{~g}^{-1}}\right)$.

The Honey-Profiling ${ }^{\mathrm{TM}}$ profile was built from the set of indicators using software for NMR spectroscopy (Table 4).

Honey-Profiling ${ }^{\mathrm{TM}}$ indicates a deviation from the norm for certain indicators. The profile of honey sample B1 contains red marks, which indicates the need for a more detailed analysis of individual indicators for this honey sample or re-analysis with NMR spectrometry (Figure 1).

If a negative result is obtained again, such samples are considered falsified. Schievano et al. (2020) recommend further CSSF-TOCSY experiments for refining the analysis to detect the sugar profile of honey and its falsification with sugar. According to their latest results, the level of fructose in the honey of European origin ranges from 36.7 to 49.4 g. $100 \mathrm{~g}^{-1}$, which coincides with our results. NMR spectroscopy allows analysis of the acid composition of honey (Table 5). 
Table 5 Acid NMR spectroscopy, mg.kg-1.

\begin{tabular}{|c|c|c|c|c|c|c|}
\hline \multicolumn{7}{|c|}{ Basic criteria } \\
\hline No. & Organic acids: & A0 & $\mathbf{A 1}$ & A2 & B1 & B2 \\
\hline 1. & Citric acid & 79 & 71 & 61 & 72 & 58 \\
\hline & Amino acids: & A0 & A1 & $\mathbf{A 2}$ & B1 & B2 \\
\hline 2. & Alanine & 11 & 7 & 8 & $\overline{\mathrm{LOQ}}$ & 8 \\
\hline 3. & Proline & 560 & 318 & 694 & 248 & 307 \\
\hline 4. & Valine & 11 & \multicolumn{4}{|c|}{$<\mathrm{LOQ}$} \\
\hline \multicolumn{7}{|c|}{ Additional parameters of fermentation, processing and origin } \\
\hline 5. & Acetic acid & 14 & 18 & 15 & 11 & $<\mathrm{LOQ}$ \\
\hline 6. & Ethanol & 21 & 6 & & $<\mathrm{LOQ}$ & \\
\hline 7. & Lactic acid & 41 & 13 & 55 & $<\mathrm{LOQ}$ & 11 \\
\hline 8. & Formic acid & 25 & 27 & 50 & 10 & 21 \\
\hline 9. & Pyruvic acid & 15 & $<\mathrm{LOQ}$ & 21 & \multicolumn{2}{|c|}{$<\mathrm{LOQ}$} \\
\hline 10. & Succinic acid & 17 & 7 & 21 & 5 & 7 \\
\hline
\end{tabular}

Note: <LOQ - below the limit of quantification.

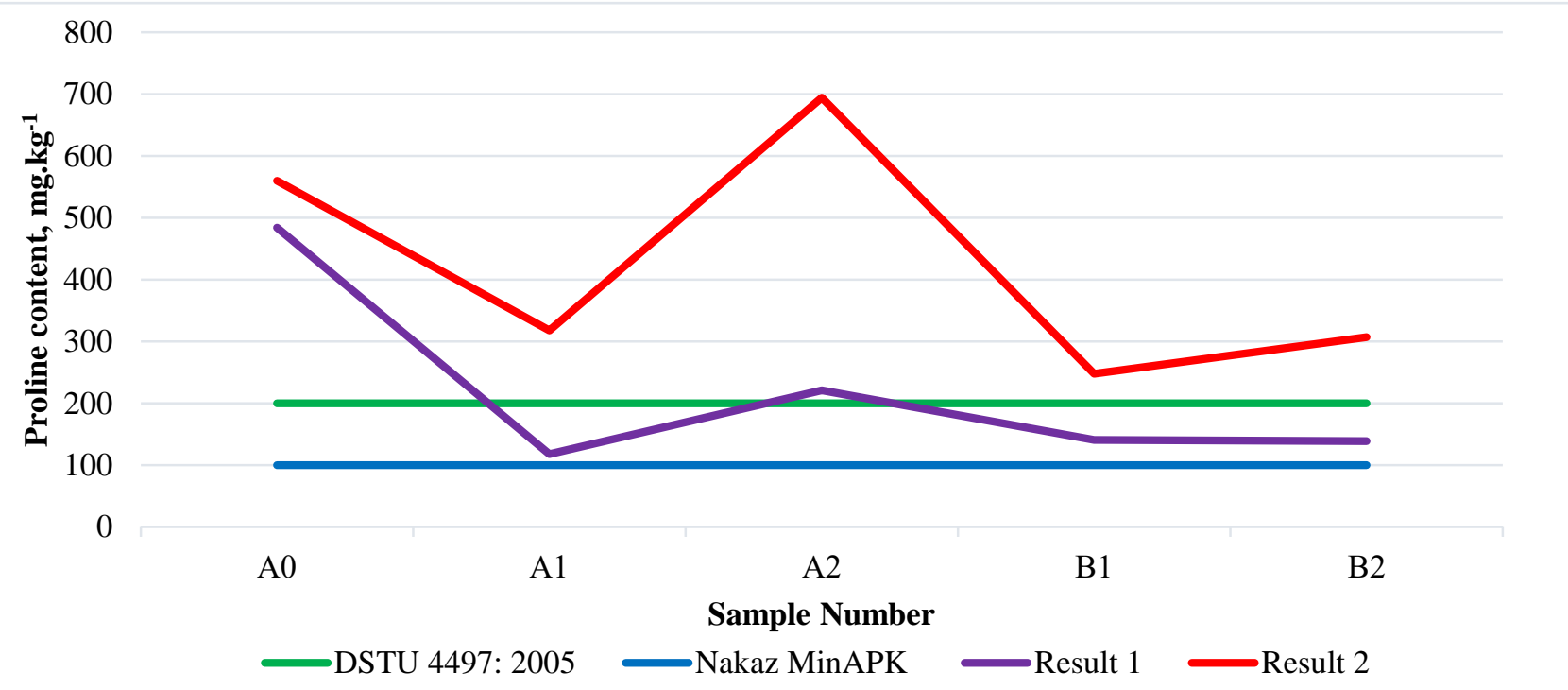

Figure 2 Proline in the investigated honey samples, $\mathrm{mg}_{\mathrm{kg}}{ }^{-1}$ : result 1 - by the method standardized according to DSTU 4497:2005 "Natural honey. Specifications"; result 2 - by NMR spectrometry.

Among organic acids, citric acid was found in the range from 58 to $79 \mathrm{mg} \cdot \mathrm{kg}^{-1}$; malic (limit of detection $\left.100 \mathrm{mg} \cdot \mathrm{kg}^{-1}\right)$ and quinic acids (300 mg. $\mathrm{kg}^{-1}$ ) were beyond the limit of quantification qualification. High proline content was characteristic of all samples tested. The highest was found in sample A2 - $694 \mathrm{mg} \cdot \mathrm{kg}^{-1}$. In general, the results from proline studies differed from those obtained using standardized techniques. Some of the amino acids were beyond quantification, namely aspartic acid (detection limit $\left.-150 \quad \mathrm{mg} \cdot \mathrm{kg}^{-1}\right)$, glutamine (200 mg. $\left.\mathrm{kg}^{-1}\right)$, leucine (40 mg. $\left.\mathrm{kg}^{-1}\right)$, tyrosine $\left(50 \mathrm{mg} \cdot \mathrm{kg}^{-1}\right)$ and phenylalanine (100 mg. $\left.\mathrm{kg}^{-1}\right)$.

A comparison of the proline indicator results obtained according to the requirements of DSTU 4497:2005 (2007) and the criteria for the honey composition according to Nakaz MinAPK No. 330 (2019) is shown in Figure 2.

In addition, special substance markers are used to identify honey from individual geographical regions. For example, for manuka honey (New Zealand), it is methylglyoxal. The markers in the test specimens were beyond quantification, namely 3-phenyl lactic acid (quantification limit - $300 \mathrm{mg} \cdot \mathrm{kg}^{-1}$ ), dihydroxyacetone (20 mg. $\left.\mathrm{kg}^{-1}\right)$, kynuric acid $\left(60 \mathrm{mg} \cdot \mathrm{kg}^{-1}\right)$, methylglyoxal (30 mg. $\left.\mathrm{kg}^{-1}\right)$ and shikimic acid (80 mg. $\left.\mathrm{kg}^{-1}\right)$.

Thus, NMR spectrometry makes it impossible to determine honey as regional (geographical definition of honey from Ukraine).

Also, additional indicators were used to control the parameters of fermentation, processing and origin (Table 5). Among these, acetic acid was detected in four test specimens, ranging from 11 to $14 \mathrm{mg} \cdot \mathrm{kg}^{-1}$; ethanol in two - from 6 to $21 \mathrm{mg} \cdot \mathrm{kg}^{-1}$; lactic acid in four - from 11 to $55 \mathrm{mg} \cdot \mathrm{kg}^{-1}$; formic acid in all samples in the range from 10 to $50 \mathrm{mg} \cdot \mathrm{kg}^{-1}$; pyruvic acid in two - from 15 to $20 \mathrm{mg} \cdot \mathrm{kg}^{-1}$; and succinic acid in all samples - from 5 to $21 \mathrm{mg} \cdot \mathrm{kg}^{-1}$. Other substances were beyond detection, namely 2,3butanediol (detection limit - $20 \quad \mathrm{mg} \cdot \mathrm{kg}^{-1}$ ), 5-hydroxymethylfurfural $\left(5 \mathrm{mg} \cdot \mathrm{kg}^{-1}\right)$, acetoin $\left(20 \mathrm{mg} \cdot \mathrm{kg}^{-1}\right)$ and fumaric acid $\left(5 \mathrm{mg} \cdot \mathrm{kg}^{-1}\right)$. All of them give an opportunity to evaluate the safety and quality of honey in terms of physicochemical composition, but do not give an understanding of its botanical origin. 


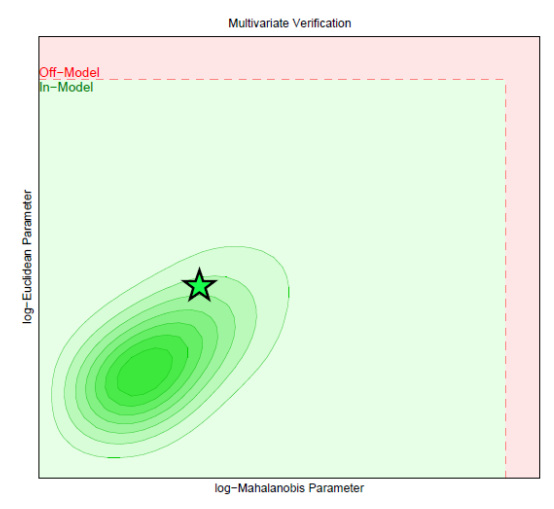

A0

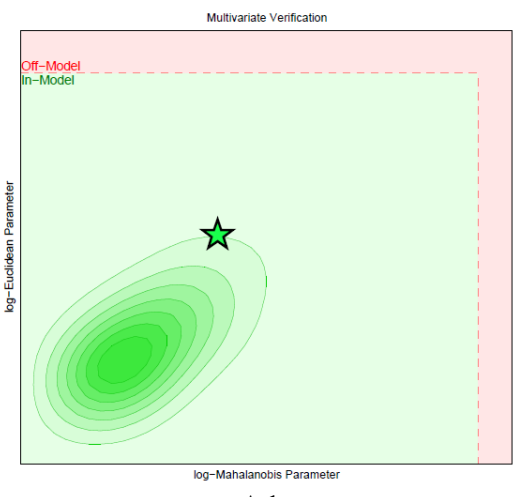

A1

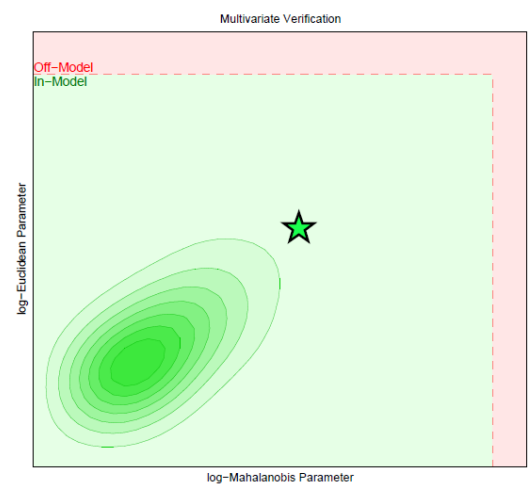

A2

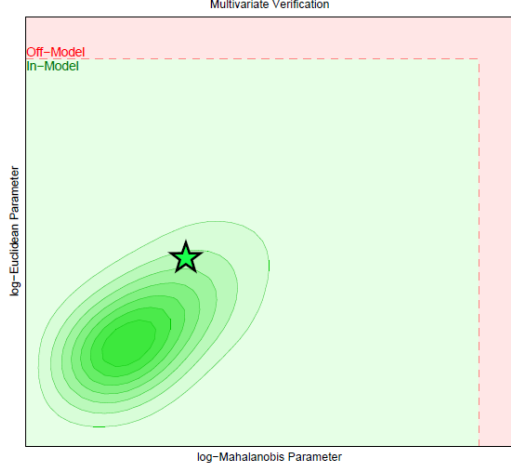

B1

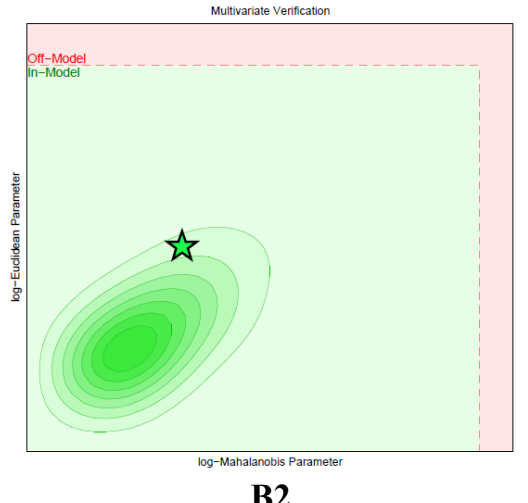

B2

Figure 3 Multivariate verification models of investigated honey.

Upon completion of the test, software verification analysis was applied and graphical models of the studied honey samples were automatically constructed (Figure 3).

Displaying the results in the form of multivariate verification models gives us a visual understanding of how much a honey sample corresponds to the declared botanical origin by the complex of physicochemical parameters studied. Thus, samples A0 and B1 are closest to the centres of correspondence (intense green colour). For this, A0 is a falsification prepared in advance.

Schievano et al. (2020) claimed that no significant differences were found in the sugar profiles in a group of European (i.e. Italian and Eastern European) acacia honeys. This allowed them to assume the minor influence of different geographical origin on the sugar profile. However, in our opinion, the sugar profile should not change significantly if the honey is natural and not falsified with sugar.

At the same time, Schievano et al. (2020) found that the sugar profile of Chinese honey purchased on the Italian market did not match. They commented on the significant decrease in endogenous sugar, which they believe is the result of feeding bees with sugar syrups during the honey harvest period. This also confirms our previous conclusions regarding the confirmation of falsification.

However, in our sample A0, which was falsified using the method of feeding bees with sugar before winter, NMR spectrometry did not detect falsification.

Along with this, there are known methods (del Campo et al., 2016; Spiteri et al., 2016), which allow the identification in honey of some species of plants, such as eucalyptus, heather, lavender, orange, thyme and rosemary. For this purpose, the authors used analysis of carboxylic acids (acetic, formic, lactic, malic and succinic acids), amino acids (alanine, phenylalanine, proline and tyrosine), carbohydrates ( $\alpha$ - and $\beta$-glucose and fructose), ethanol and hydroxymethylfurfural.

Gerhardt et al. (2018) presented results where they were able to distinguish three varieties of honey, namely canola, acacia and honeydew honeys, with a predictive accuracy of $98.6 \%$ using additional HS-GC-IMS profiling.

Schievano et al. (2020) asserted that melissopalynological analysis and SCIRA also do not reveal any particular anomalies in Chinese acacia honey samples. This is probably due to new methods of falsification. According to our previous research (Adamchuk, Suchenko and Akulonok, 2019), pollen analysis of honey using harmonized methods (Von Der Ohe et al., 2004), which we adapted to the laboratory conditions of Ukraine, is reliable in the botanical identification of honey. Thus, in the 30 acacia honey samples tested, we found $20 \%$ to $30 \%$ Robinia pseudoacacia pollen grains. This indicates compliance with the current standards for acacia monofloral honey in Ukraine (Nakaz MinAPK No. 330, 2019). In this case, the tested honey samples also met the requirements for diastasis and hydroxymethylfurfural.

For evaluation of the botanical origin of honey, the NMR spectrometry method proved to be ineffective for our samples. All honey was programmatically identified as polyfloral. Therefore, we applied the harmonized method of melissopalynology (Von Der Ohe et al., 2004), which we adapted to the conditions of the laboratory at the Department of Certification and Standardization of Agricultural Products, NULES of Ukraine; and improved the way of counting and identifying pollen grains of different types of plants widespread in Ukraine.

The results of pollen analysis are shown in Table 6. 
Table 6 Botanical origin of honey.

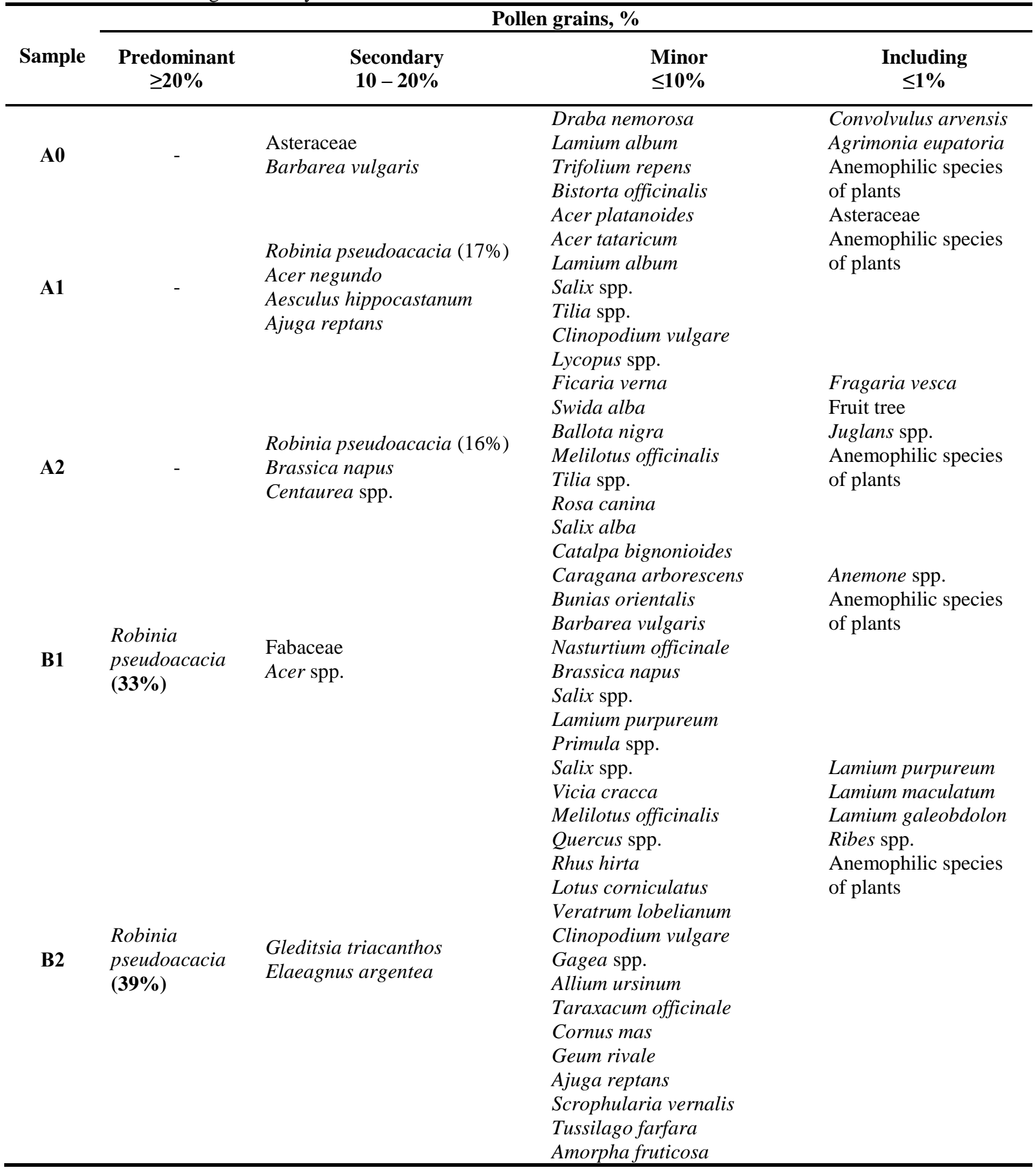

According to the results of the research, samples B1 and B2 correspond to the acacia variety by botanical origin. They contain 33\% and 39\% acacia (Robinia pseudoacacia) pollen grains, respectively. According to Nakaz MinAPK No. 330 (2019), the only normative document regulating the criteria for monofloral honey varieties, for acacia honey, the Robinia pseudoacacia pollen grain content should be at least $20 \%$.

Samples A1 and A2 also contained acacia grains, 17\% and $16 \%$, respectively. Along with this, sample A1 also contained a large amount of pollen from maple (A. negundo, A. platanoides, A. tataricum), horse-chestnut
(A. hippocastanum) and bugleweed (A. reptans). Sample A2 contained a significant amount of pollen from rapeseed (B. napus) and several species of Centaurea spp., indicating the activation of flight activity of bees on field honey plants after the end of acacia flowering. The presence of willow (Salix spp.) pollen grains indicates a failure of adherence to acacia honey production technology, which is based on the use of additional cases of the 145-frame hive. Pollen from willow, which is an early pollen source, can only be present in the hive body.

The conducted studies confirm the need for a comprehensive approach to the identification of the 
botanical origin of honey for its conformity to the acacia variety. There is a need to revise the physicochemical indicators regarding the conformity of honey obtained in Ukraine to the acacia variety. After all, even the modern NMR spectrometry technique indicated that sample A0, which did not contain acacia pollen grains and was specially fabricated, was acacia honey.

\section{CONCLUSION}

Identification of the botanical origin of monofloral kinds of honey, in particular acacia, should be carried out in the following sequence: pollen analysis (by dominant pollen grains), safety (presence of antibiotics, pesticides), physicochemical parameters according to international requirements, organoleptic parameters. The methods of determination and requirements for physicochemical indicators of honey require revision, improvement and harmonization.

In the future, the safety of acacia honey in terms of the content of contaminants that may be caused by anthropogenic environmental load requires analysis and research. Also, there is a necessity to find markers that will indicate the geographical origin of Ukrainian kinds of honey and thus protect them from falsification from other countries.

\section{REFERENCES}

Adamchuk, L. O., Suchenko, V. Y., Akulonok, I. 2019. Fermentatyvna aktyvnist akatsiievoho medu (Enzymatic activity of acacia honey). Novitni Tekhnolohii (New Technologies), vol. 3 , no. 10, p. 52-61. https://doi.org/10.31180/2524-0102/2019.3.10.06

Ampuero, S., Bogdanov, S., Bosset, J. O. 2004. Classification of unifloral honeys with an MS-based electronic nose using different sampling modes: SHS, SPME and INDEX. European Food Research and Technology, vol. 218, no. 2, p. 198-207. https://doi.org/10.1007/s00217-0030834-9

Ballabio, D., Robotti, E., Grisoni, F., Quasso, F., Bobba, M., Vercelli, S., Gosetti, F., Calabrese, G., Sangiorgi, E., Orlandi, M., Marengo, E. 2018. Chemical profiling and multivariate data fusion methods for the identification of the botanical origin of honey. Food Chemistry, vol. 266, no. 15, p. 79-89. https://doi.org/10.1016/j.foodchem.2018.05.084

Brindza, J., Motyleva, S., Ostrovský, R., Grygorieva, O., Adamchuk, L., Horčinova Sedlačková, V., Juríková, T., Fatrcová-Šramková, K., Shwaryová, M., Brovaskyi, V., Velychko, S., Tkachenko, O. 2018. Pel' a včelie pel'ové obnôžky z niektorých druhov rastlín (Pollen and bee pollen same plant species). Nitra : SPU v Nitre, 147 p. ISBN 97880-552-1862-5 (In Slovak).

Bruker, 2020. High-performance scientific instruments and analytical and diagnostic solutions to explore life and materials at molecular level. Available at: https://www.bruker.com/ru.html.

Carreck, N. L. 2018. Special issue: honey. Journal of Apicultural Research, vol. 57, p. 1-4. https://doi.org/10.1080/00218839.2017.1412565

Chekryga, G. P., Niczievskaya, K. N., Borodaj, E. V. 2019. A new method for determining the botanical origin of honey (Новый метод определения ботанического происхождения меда). Advances in Science and Technology AIC (Достижения науки и техники АПК), vol. 33, no. 10, p. 90-92. https://doi.org/10.24411/0235-2451-2019-11020 (In Russian)

Corvucci, F., Nobili, L., Melucci, D., Grillenzoni, F.-V. 2015. The discrimination of honey origin using melissopalynology and Raman spectroscopy techniques coupled with multivariate analysis. Food Chemistry, vol. 169, no. 15, p. 297-304. https://doi.org/10.1016/j.foodchem.2014.07.122

Cozzolino, D., Corbella, E., Smyth, H. 2011. Quality control of honey using infrared spectroscopy: a review. Applied Spectroscopy Reviews, vol. 46, no. 7, p. 523-538. https://doi.org/10.1080/05704928.2011.587857

del Campo, G., Zuriarrain, J., Zuriarrain, A., Berregi, I. 2016. Quantitative determination of carboxylic acids, amino acids, carbohydrates, ethanol and hydroxymethylfurfural in honey by 1H NMR. Food Chemistry, vol. 196, p. 1031-1039. https://doi.org/10.1016/j.foodchem.2015.10.036

Dinca, O. R., Ionete, R. E., Popescu, R., Costinel, D., Radu G. L. 2015. Geographical and botanical origin discrimination of Romanian honey using complex stable isotope data and chemometrics. Food Analytical Methods, vol. 8, no. 2, p. 401412. https://doi.org/10.1007/s12161-014-9903-x

DSTU 4497:2005. 2007. Natural honey. Technical requirements. (Med naturalnyi. Tekhnichni umovy). National Standards of Ukraine (Derzhavni standarty Ukrainy). (In Ukrainian).

Etzold, E., Lichtenberg-Kraag, B. 2008. Determination of the botanical origin of honey by Fourier-transformed infrared spectroscopy: an approach for routine analysis. European Food Research and Technology, vol. 227, no. 2, p. 579-586. https://doi.org/10.1007/s00217-007-0759-9

Gan, Z., Yang, Y., Li, J., Wen, X., Zhu, M., Jiang, Y., Ni, Y. 2016. Using sensor and spectral analysis to classify botanical origin and determine adulteration of raw honey. Journal of Food Engineering, vol. 178, p. 151-158. https://doi.org/10.1016/j.jfoodeng.2016.01.016

Gerhardt, N., Birkenmeier, M., Schwolow, S., Rohn, S., Weller, P. 2018. Volatile-compound fingerprinting by headspace-gas-chromatography ion-mobility spectrometry (HS-GC-IMS) as a benchtop alternative to $1 \mathrm{H}$ NMR profiling for assessment of the authenticity of honey. Analytical Chemistry, vol. 90, no. 3, p. 1777-1785. https://doi.org/10.1021/acs.analchem.7b03748

Global Industry Analysts Inc. USA. 2016. Honey: a global strategic business report. San Jose, CA : Global Industry Analysts Inc. Available at: http://www.strategyr.com/MarketResearch/Honey_Market_Tr ends.asp).

Gok, S., Severcan, M., Goormaghtigh, E., Kandemir, I., Severcan, F. 2015. Differentiation of Anatolian honey samples from different botanical origins by ATR-FTIR spectroscopy using multivariate analysis. Food Chemistry, vol. 170, no. 1, p. 234-240. https://doi.org/10.1016/j.foodchem.2014.08.040

Hong, E. J., Park, S. J., Lee, H. J., Lee, K. G., Noh, B. S. 2011. Analysis of various honeys from different sources using electronic nose. Korean Journal for Food Science of Animal Resources, vol. 31, no. 2, p. 273-279. https://doi.org/10.5851/kosfa.2011.31.2.273

Huang, L., Liu, H., Zhang, B., Di, W. 2015. Application of electronic nose with multivariate analysis and sensor selection for botanical origin identification and quality determination of honey. Food and Bioprocess Technology, vol. 8, p. 359-370. https://doi.org/10.1007/s11947-014-1407-6

Ivanišová, E., Kačániová, M., Frančáková, H., Petrová, J., Hutková, J., Brovarskyi, V., Velychko, S., Adamchuk, L., 
Schubertová, Z., Musilová, J. 2015. Bee bread-perspective source of bioactive compounds for future. Potravinarstvo Slovak Journal of Food Sciences, vol. 9, no. 1, p. 592-598. https://doi.org/10.5219/558

Lenhardt, L., Bro, R., Zeković, I., Dramićanin, T., Dramićanin, M. D. 2015. Fluorescence spectroscopy coupled with PARAFAC and PLS DA for characterization and classification of honey. Food Chemistry, vol. 175, no. 15, p. 284-291. https://doi.org/10.1016/j.foodchem.2014.11.162

Machado De-Melo, A. A., Bicudo de Almeida-Muradian, L., Sancho, T. M., Pascual-Maté, A. 2018. Composition and properties of Apis mellifera honey: a review. Journal of Apicultural Research, vol. 57. p. 5-37. https://doi.org/10.1080/00218839.2017.1338444

Maione, C., Barbosa, F., Jr., Barbosa, R. M. 2019. Predicting the botanical and geographical origin of honey with multivariate data analysis and machine learning techniques: a review. Computers and Electronics in Agriculture, vol. $\quad 157$, p. 436-446. https://doi.org/10.1016/j.compag.2019.01.020

Marghitas, L. A., Dezmirean, D. S., Pocol, C. B., Marioara, I. L. E. A., Bobis, O., Gergen, I. 2010. The development of a biochemical profile of acacia honey by identifying biochemical determinants of its quality. Notulae Botanicae Horti Agrobotanici Cluj-Napoca, vol. 38, no. 2, p. 84-90. https://doi.org/10.15835/nbha3824780

Nakaz MinAPK No. 330, 2019. On approval of the requirements for honey: Order of Ministry of Agrarian Policy and Food of Ukraine (Pro zatverdzhennia Vymoh do medu: Nakaz Ministerstva ahrarnoi polityky ta prodovolstva Ukrainy). Available

https://zakon.rada.gov.ua/laws/show/z0725-19. (In Ukrainian)

Oddo, L. P., Piro, R., Bruneau, É., Guyot-Declerck, C., Ivanov, T., Piskulová, J., Flamini, C., Lheritier, J., Morlot, M., Russmann, H., Von Der Ohe, W., Von Der Ohe, K., Gotsiou, P., Karabournioti, S., Kefalas, P., PassaloglouKatrali, M., Thrasyvoulou, A., Tsigouri, A., Marcazzan, G. L., Piana, M. L., Piazza, M. G., Sabatini, A. G., Kerkvliet, J., Godinho, J., Bentabol, A., Valbuena, A. O., Bogdanov, S., Ruoff, K. 2004. Main European unifloral honeys: descriptive sheets. Apidologie, vol. 35, suppl. 1, p. 38-81. https://doi.org/10.1051/apido:2004049

Pascual-Maté, A., Osés, S. M., Fernández-Muiño, M. A., Sancho, M. T. 2018. Methods of analysis of honey. Journal of Apicultural Research, vol. 57, p. 38-74. https://doi.org/10.1080/00218839.2017.1411178

Peng Kek, S., Ling Chin, N., Yusof, Y. A., Wei, Tan, S., Suan Chua, L. 2017. Classification of entomological origin of honey based on its physicochemical and antioxidant properties. International Journal of Food Properties, vol. 20, p.

https://doi.org/10.1080/10942912.2017.1359185

SAS, 2009. Users guide version 9.2. Cary, NC, USA : SAS/STAT (r)SAS Institute Inc.

Schievano, E., Sbrizza, M., Zuccato, V., Piana, L., Tessari, M. 2020. NMR carbohydrate profile in tracing acacia honey authenticity. Food Chemistry, vol. 309, 125788. https://doi.org/10.1016/j.foodchem.2019.125788

Siddiqui, A. J., Musharraf, S. G., Choudhary, I., Rahman, A. 2017. Application of analytical methods in authentication and adulteration of honey. Food Chemistry, vol. 217, no. 15, p. 687-698. https://doi.org/10.1016/j.foodchem.2016.09.001

Soares, S., Amaral, J. S., Oliveira, M. B., Mafra, I. 2015. Improving DNA isolation from honey for the botanical origin identification. Food Control, vol. 48. p. 130-136. https://doi.org/10.1016/j.foodcont.2014.02.035
Son, Y. Q., Milne, R. I., Zhou, H. X., Ma, X. L., Fang, J. Y., Zha, H. G. 2019. Floral nectar chitinase is a potential marker for monofloral honey botanical origin authentication: a case study from loquat (Eriobotrya japonica Lindl.). Food Chemistry, vol. 282, no. 1, p. 76-83. https://doi.org/10.1016/j.foodchem.2018.12.107

Spiteri, M., Dubin, E., Cotton, J., Poirel, M., Corman, B., Jamin, E., Lees, M., Rutledge, D. 2016. Data fusion between high resolution $1 \mathrm{H}-\mathrm{NMR}$ and mass spectrometry: a synergetic approach to honey botanical origin characterization. Analytical and Bioanalytical Chemistry, vol. 408, no. 16, p. 4389-4401. https://doi.org/10.1007/s00216016-9538-4

Thrasyvoulou, A., Tananaki, C., Goras, G., Karazafiris, E., Dimou, M., Liolios, V., Kanelis, D., Gounari, S. 2018. Legislation of honey criteria and standards. Journal of Apicultural Research, vol. 57, p. 88-96. https://doi.org/10.1080/00218839.2017.1411181

Ulloa, P. A., Guerra, R., Cavaco, A. M., Rosa da Costa, A. M., Figueira, A. C., Brigas, A. F. 2013. Determination of the botanical origin of honey by sensor fusion of impedance etongue and optical spectroscopy. Computers and Electronics in Agriculture, vol. 94, p. 1-11. https://doi.org/10.1016/j.compag.2013.03.001

Von Der Ohe, W., Oddo, L. P., Piana, M. L., Morlot, M., Martin, P. 2004. Harmonized methods of melissopalynology. Apidologie, vol. 35, suppl. $1, \quad$ p. 18-25. https://doi.org/10.1051/apido:2004050

\section{Acknowledgments:}

Author Leonora Adamchuk thanks the International Visegrad Fund (ID 51910842) for scholarship and research internships, during which the results and knowledge presented in this paper were obtained. The publication was prepared with the active participation of researchers involved in the international network AgroBioNet from the Institutions and Researchers for Realization of Research, Education and Development Program (Agrobiodiversity for improving nutrition, health and life quality) TRIVE (ITMS 26110230085).

The authors are thankful to the management and staff of the laboratories of Bruker BioSpin GmbH (Germany) for their cooperation and the opportunity to analyse the honey samples for free.

\section{Contact address:}

Leonora Adamchuk, National University of Life and Environmental Sciences of Ukraine, Faculty of Food Technology and Quality Control of Agricultural Products, Department of Standardization and Certification of Agricultural Products, Polkovnika Potekhina Str. 16, 03041 Kyiv, Ukraine, Tel.: +380976906588,

E-mail: leonora.adamchuk@gmail.com ORCID: https://orcid.org/0000-0003-2015-7956

*Vladyslav Sukhenko, National University of Life and Environmental Sciences of Ukraine, Faculty of Food Technology and Quality Control of Agricultural Products, Department of Standardization and Certification of Agricultural Products, Polkovnika Potekhina Str. 16, 03041 Kyiv, Ukraine, Tel.: +380668182099,

E-mail: vladsuhenko@gmail.com ORCID: https://orcid.org/0000-0002-8325-3331

Oleksandra Akulonok, National University of Life and Environmental Sciences of Ukraine, Faculty of Livestock Raising and Water Bioresources, Department of Horse- 
Breeding and Beekeeping, General Rodimtsev Str. 19, 03041 Kyiv, Ukraine, Tel.: +380953910876,

E-mail: igorivna9@gmail.com

ORCID: https://orcid.org/0000-0002-1247-5017

Tetiana Bilotserkivets, PrJSC Myronivsky Hliboproduct, Production and Technological Centre for Quality and Safety Control of Food, Compound Feeds and Feed Materials, Laboratory of Physico-Chemical Research, Myru Str. 19, 03043 Kyiv, Ukraine, Tel.: +380976248887, E-mail: bilocerkivec_ti@ukr.net

ORCID: https://orcid.org/0000-0001-9676-191X

Volodymyr Vyshniak, National University of Food, Faculty of Biotechnology and Environmental Control, Department of Physics, Volodymyrska Str. 68, 01601 Kyiv, Ukraine, Tel.: +380508292736,

E-mail: vladimir_kiev@i.ua

ORCID: https://orcid.org/0000-0003-1370-0228

Dina Lisohurska, Zhytomyr National Agroecological University, Faculty of Technology, Department of Animal Production Technologies, Korolev Str. 39, 10025, Zhytomyr, Ukraine, Tel.: +380969641003,

E-mail: lisogurskadina@gmail.com

ORCID: https://orcid.org/0000-0002-2559-6520

Olha Lisohurska, Zhytomyr National Agroecological University, Faculty of Technology, Department of Animal Production Technologies, Korolev Str. 39, 10025, Zhytomyr, Ukraine, Tel.: +380412330982,
E-mail: lisogurskaya2016@gmail.com

ORCID: https://orcid.org/0000-0002-3553-9351

Natalia Slobodyanyuk, National University of Life and Environmental Sciences of Ukraine, Faculty of Food Technology and Quality Control of Agricultural Products, Department of Technologies of Meat, Fish and Marine Products, Polkovnika Potekhina Str. 16, 03041 Kyiv, Ukraine, Tel.: +380982768508,

E-mail: slob2210@ukr.net

ORCID: https://orcid.org/0000-0002-7724-2919

Olga Shanina, Kharkiv Petro Vasylenko National Technical University of Agriculture, Department of Technologies of Processing and Food Industries, Alchevsky Str. 44, 61002, Kharkiv, Ukraine, Tel.: +380509103205,

E-mail: o.shanina.ua@gmail.com

ORCID: https://orcid.org/0000-0003-2465-1257

Ivan Galyasnyj, Kharkiv Petro Vasylenko National Technical University of Agriculture, Department of Technologies of Processing and Food Industries, Alchevsky Str. 44, 61002, Kharkiv, Ukraine, Tel.: +380577730149,

E-mail: ivangalyasnyj@yandex.ru

ORCID: https://orcid.org/0000-0002-4195-9694

Corresponding author: * 